\title{
Urgences
}

\section{Variations sur une naissance}

\section{Michelle Dubois}

Numéro 5, 3e trimestre 1982

URI : https://id.erudit.org/iderudit/025080ar

DOI : https://doi.org/10.7202/025080ar

Aller au sommaire du numéro

Éditeur(s)

Urgences

ISSN

0226-9554 (imprimé)

1927-3924 (numérique)

Découvrir la revue

Citer ce document

Dubois, M. (1982). Variations sur une naissance. Urgences, (5), 73-81.

https://doi.org/10.7202/025080ar

Ce document est protégé par la loi sur le droit d'auteur. L'utilisation des services d'Érudit (y compris la reproduction) est assujettie à sa politique d'utilisation que vous pouvez consulter en ligne.

https://apropos.erudit.org/fr/usagers/politique-dutilisation/
Cet article est diffusé et préservé par Érudit.

Érudit est un consortium interuniversitaire sans but lucratif composé de l’Université de Montréal, l'Université Laval et l'Université du Québec à Montréal. Il a pour mission la promotion et la valorisation de la recherche. https://www.erudit.org/fr/ 
MICHELLE DUBOIS

Variations sur une naissance 
naissance au bout du silence

pierre sur la route des sables

léger bandeau de feu au ras des bouches

à peine

et dit entre deux virgules

un jeudi de mars dans l'espace de l'archet 
la fumée sortilège poursuit son désespoir un cercle se camoufle gris

peur la source rira-t-elle des lacs étales avant de tarir

et de jeter son âme au désert

pour un instant de claire sécheresse

et l'insatiable écho du soleil sur les vagues sableuses 
le paysage blanc fait pleurer la fenêtre le sang remonte à la source

la colère du coeur

une assiette vide encercle une petite fin

le rideau tiré

tout un espace tendu

vers un mot qui glisse sur la nappe

échappé belle 
un poème en forme d'évidence

I'anse bleue du gobelet

pour porter le vin à l'ivresse

et des mots rouges dans nos gorges

ce soir la braise a le bon goût des fruits bien mûrs 
cependant les minutes se tassent

et les murs craquent

pas de répit pour la main sur la peau

à colmater les fuites

dans l'attention féconde

retenir le chant

jusqu'à l'or du cri perce-neige 
au matin un ravage compose le texte les bras au coeur du fardeau chaque pauvre regard accroché aux épaules le souffle décapité avancer au filet pêcher les eaux recluses dans I'entrebâillement des ventres mous 
l'oeil court devant la chute des syllabes et mesure l'espace piège des ressorts sonores dans la bouche l'alarme je glisse sur la salive les dents mordent le papier miroir pour un reflet défiguré 
volutes pour deux mains fumée perdue encre éperdue l'espace fugace au centre poitrine qui monte et s'abaisse dans le rythme des courbes une haleine accueille la naissance des bruits et les dépose sur les lèvres parole vive et menacée $\mathrm{d}^{\prime} \mathrm{ici}$ à vous 